\title{
Squaring Circles: The Regional and the "Foreign" in the Art of Jack Chambers
}

\author{
Mark A. Cheetham
}

Volume 38, numéro 1, 2013

URI : https://id.erudit.org/iderudit/1066664ar

DOI : https://doi.org/10.7202/1066664ar

Aller au sommaire du numéro

\section{Éditeur(s)}

UAAC-AAUC (University Art Association of Canada | Association d'art des universités du Canada)

ISSN

0315-9906 (imprimé)

1918-4778 (numérique)

Découvrir la revue

Citer cet article

Cheetham, M. A. (2013). Squaring Circles: The Regional and the "Foreign" in the Art of Jack Chambers. RACAR : Revue d'art canadienne / Canadian Art Review, 38(1), 55-64. https://doi.org/10.7202/1066664ar

\section{Résumé de l'article}

L’art de Jack Chambers est souvent décrit et défini comme étant régional, soit profondément représentatif de London et de l'Ontario du sud-ouest. S'il est vrai que plusieurs éléments viennent soutenir ce point de vue - dans les tableaux et films de Chambers comme dans ses écrits -, celui-ci demeure incomplet et même trompeur. Nous pouvons raconter une histoire différente de Chambers et des environs de London, une histoire qui rend paradoxale l'étiquette régionaliste qui lui est généralement accolée. De surcroît, cette lecture alternative, qui découle d'une mise en valeur d'autres éléments, nous permet de jeter un regard nouveau sur une grande partie de l'oeuvre de Chambers, y compris « Perceptual Realism » (1969), son essai difficile qui a souvent laissé ses lecteurs perplexes, ainsi que son film Hybrid (1967). L'habitude de Chambers d'emprunter des motifs provenant de la tradition européenne classique, qu'il a activement émulée à travers ses souvenirs personnels de son éducation en Espagne et ses associations avec London et ses environs, fait de son régionalisme une valeur interne - et non une affiliation provinciale qu'il a tenté d'expliquer dans son autobiographie (1978) en décrivant le perceptual realism comme une « faculty of inner vision ». Comment réconcilier le régional et l'international dans l'oeuvre de Chambers ? Il nous montre que ces dimensions de la réalité coexistent nécessairement partout, si seulement nous pouvons les percevoir : dans London, dans l'artiste, dans la dynamique de la mémoire humaine, et particulièrement dans le jeu entre le conscient et l’inconscient, ce théâtre palpable de l'esprit que ses films reflètent si puissamment.
Tous droits réservés (C) UAAC-AAUC (University Art Association of Canada | Association d'art des universités du Canada), 2013
Ce document est protégé par la loi sur le droit d'auteur. L’utilisation des services d'Érudit (y compris la reproduction) est assujettie à sa politique d'utilisation que vous pouvez consulter en ligne.

https://apropos.erudit.org/fr/usagers/politique-dutilisation/ 


\title{
Squaring Circles: The Regional and the "Foreign" in the Art of Jack Chambers
}

\author{
Mark A. Cheetham, University of Toronto
}

\begin{abstract}
Résumé
L'art de Jack Chambers est souvent décrit et défini comme étant régional, soit profondément représentatif de London et de l'Ontario du sudouest. S'il est vrai que plusieurs éléments viennent soutenir ce point de vue — dans les tableaux et films de Chambers comme dans ses écrits — celui-ci demeure incomplet et même trompeur. Nous pouvons raconter une histoire différente de Chambers et des environs de London, une histoire qui rend paradoxale l'étiquette régionaliste qui lui est généralement accolée. De surcroît, cette lecture alternative, qui découle d'une mise en valeur d'autres éléments, nous permet de jeter un regard nouveau sur une grande partie de l'œuvre de Chambers, y compris « Perceptual Realism » (1969), son essai difficile qui a souvent laissé ses lecteurs perplexes, ainsi que son film Hybrid (1967). L'habitude de Chambers d'emprunter des motifs provenant de la tradition européenne classique, qu'il a activement émulée à travers ses souvenirs personnels de son éducation en Espagne et ses associations avec London et ses environs, fait de son régionalisme une valeur interne — et non une affiliation provinciale — qu'il a tenté d'expliquer dans son autobiographie (1978) en décrivant le perceptual realism comme une « faculty of inner vision ». Comment réconcilier le régional et l'international dans l'œuvre de Chambers ? II nous montre que ces dimensions de la réalité coexistent nécessairement partout, si seulement nous pouvons les percevoir : dans London, dans l'artiste, dans la dynamique de la mémoire humaine, et particulièrement dans le jeu entre le conscient et l'inconscient, ce théâtre palpable de l'esprit que ses films reflètent si puissamment.
\end{abstract}

$\mathrm{T}_{\mathrm{h}}$ he art of Jack Chambers is often described and defined as regional, as deeply representative of London and Southwestern Ontario. ${ }^{1}$ Supporting this view are his many paintings of area scenes, most famously 401 Towards London No. 1 (1968-69); his habitual use of found, local news footage and still photographs of local people and scenes in several of his films; and statements by Chambers himself about the significance of the area to his life and work. In his autobiography, for example, published posthumously by his friend and art dealer, Nancy Poole, ${ }^{2}$ he describes how he decided to stay in London after returning from Spain in April 1961 to be with his terminally ill mother: "It was a feel for the place that produced my intention to stay on in London. It was also my home town, and there were spaces here along the river and in the landscape that had become mine years ago and continued to be so" (88). This account, written late in Chambers's life, is consistent with his answer to interviewer Ross Woodman's blunt question to him in 1966: "why did you return to Canada?," in which he suggests he could never get "inside" the Castillian landscape. ${ }^{3}$ Chambers was also encouraged to return to London by its then burgeoning local art and gallery scene, promoted vigorously by his close friend Greg Curnoe. The advantages were partly financial. He could sell his work more readily and he could be a full time artist. "When I left London in the fifties," Chambers writes in his autobiography, "no one was painting full time. Greg [Curnoe] was the first one to do so in London" (105). There was also artistic inspiration in Toronto and New York City, given that he was just becoming aware of recent American and European art that he could not see in Franco's Spain. Characteristically too, Chambers was practical: "There were certainly more possibilities to survive in Canada than there were for a Canadian in Spain" (93).

There is no question that Chambers was personally and artistically dedicated to place, to the London area and its human and natural surroundings. Autobiographical and biographical details about the intertwining of Chambers's life and art are so abundant that commentators can easily forget, however, that such details are not transparent in his art or indeed in his writings. Both the artist himself and anyone working with these materials is of necessity selective in presenting a cogent narrative. Weighing all the evidence judiciously in what is the most complete biography of Chambers to date, Dennis Reid wrote in 2011, "It seems clear that even before the death of his mother in August [1962], he had decided to remain in Canada, in London." 4 If we assume that this is the best interpretation, the prime question should then be how we understand the range of work Chambers produced from mid-1961 until his premature death at age forty-seven from leukemia in 1978. We can tell a quite different story about Chambers and the London area, one that makes the regionalist tag he usually carries paradoxical. More importantly, this alternative reading-a matter of different emphasis - can allow us to see much of Chambers's remarkable artistic work differently, including his difficult and much puzzled-over essay "Perceptual Realism" (1969).

With his usual penetrating wisdom, English professor and Chambers's close friend since 1952 Ross Woodman wrote recently that "the regionalism that is...an issue...in Chambers's work cannot be avoided. Indeed, no art can avoid it." 5 As Woodman implies, the paradox of the regional is that it is not only regional. The corollary also holds true: even the most nationally and internationally minded artist-which Chambers was, though many scholars have neglected this part of his makeup, arguably because they make assumptions about the nature of his regionalism-is formed in part by his beginnings, whether of light and the landscape (as we saw, Chambers lamented in the 1966 interview with Woodman that he could never fully understand the land in Spain) or of markers of 


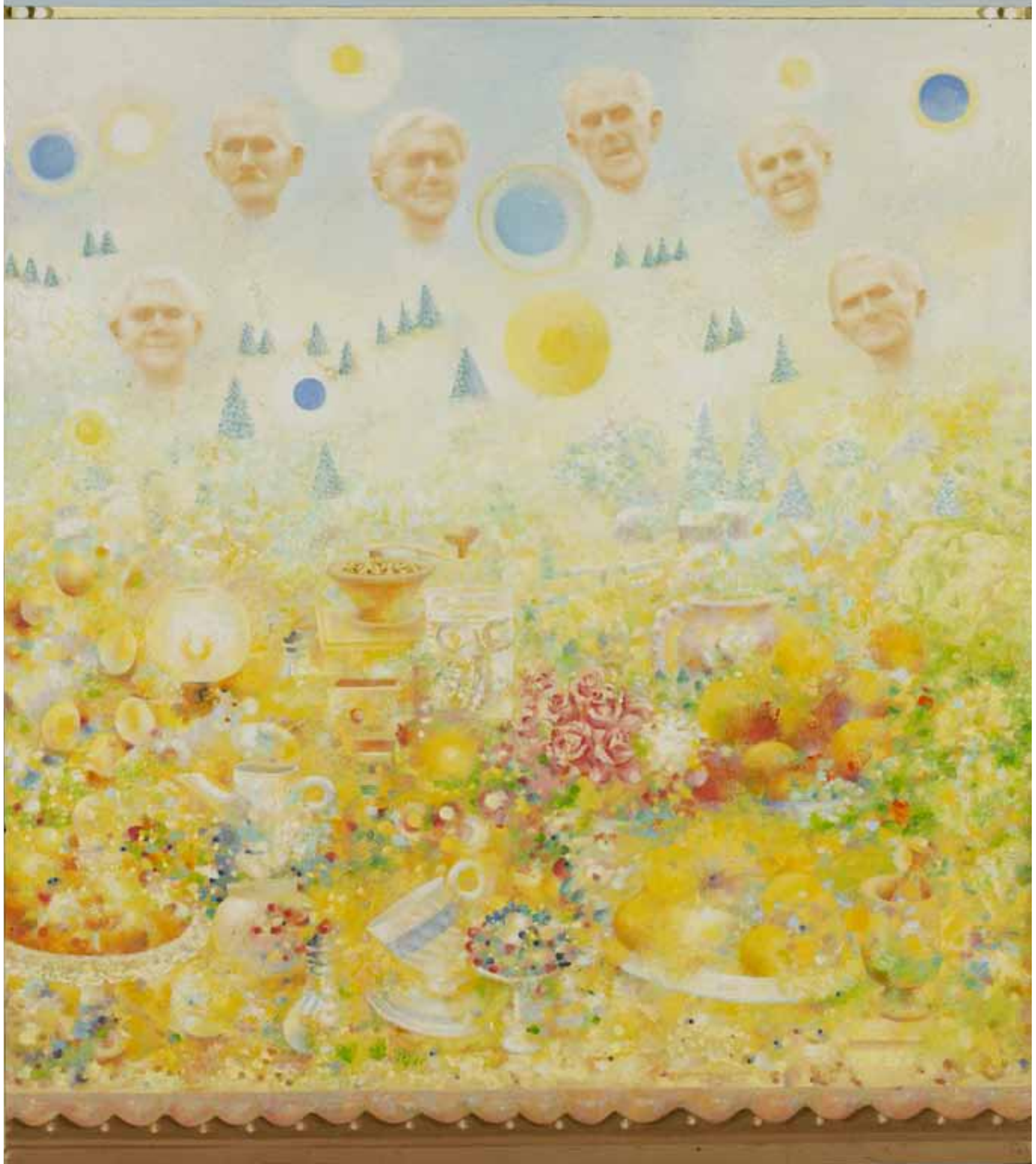

Figure I. McGilvary County, 1962. Oil and mixed media on wood, $132.9 \times 120 \mathrm{~cm}$, purchased with the assistance of The Judith Rachel Harris Foundation and Ethel Harris, 2007. Art Gallery of Ontario (Photo: Art Gallery of Ontario). 
culture. To appreciate how profound and complex Chambers was as a regional artist, then, we need to acknowledge and explore the foreignness that punctuated his regionalism.

Chambers tells us in his autobiography that as a young man he was frustrated with London, Ontario. He escaped to Quebec City for two weeks and later to Mexico. Why? "There were things I tried to do and couldn't do [in London], and I didn't think that what I was looking for was to be found in Canada or the USA. Actually, I didn't know what I was looking for, but whatever it was it didn't seem to be close by" (40). He worked three jobs after dropping out of first year studies at what was then the University of Western Ontario in order to save money for travel. He left for Europe in 1952, lived in Spain from 1956 onwards, and bought an apartment in Madrid. Even on hearing of his mother's illness in 1961, he left Spain "thinking I would be back in a few weeks" (88). In the early 1960s he exhibited in Madrid and in New York. Though he was from this time aware of the most demanding contemporary art and both incorporated and challenged Andy Warhol in his own silver paintings and films, ${ }^{6}$ his artistic reputation in Canada has rested largely on his overtly regionalist and-in contrast to his concomitant experimental films-traditional paintings such as 401 Towards London No. 1 and his later Lake Huron series, the work that he called "perceptual realism."7

Chambers's psyche was haunted by the London area. Its ghosts-his ghosts_-appear often: in McGilvary County (1962; Fig. 1), he famously floated the visages of dead relatives above a table set for a celebratory meal. Derived initially from family

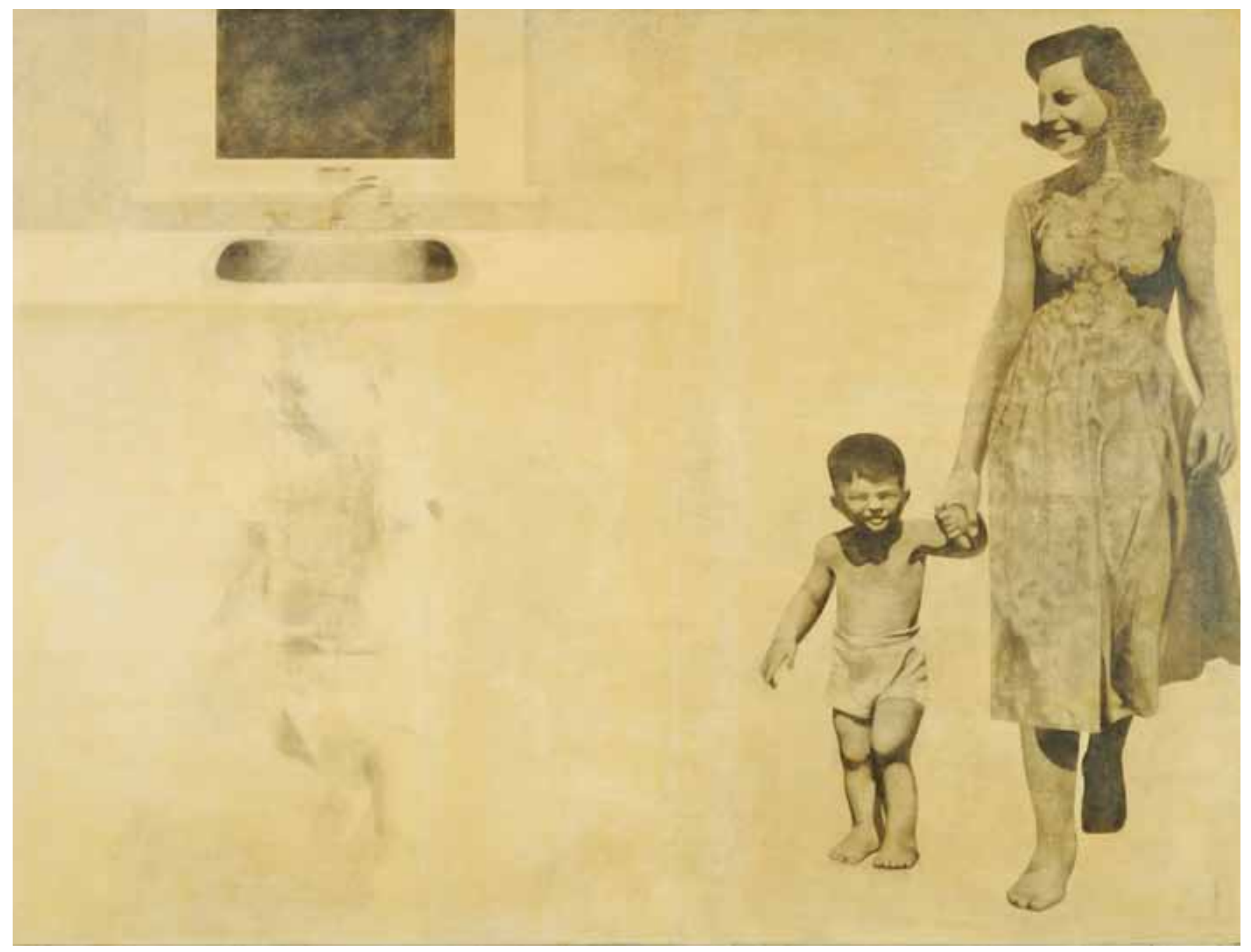

Figure 2. Moving Side \& Forward, 1967. Graphite powder and Hyplar spray on paper, on particle board, $140 \times 185.5 \mathrm{~cm}$. Collection of the Art Gallery of York University (Photo: Art Gallery of York University). 
photographs, Chambers incorporated these faces into his painting and later drew "studies" of them, suggesting that they were present for him psychically. The leftmost woman in Three Sisters Waiting (1964) is all but invisible, yet her spectre haunts the painting. The appearance of Chambers's laughing infant son at the left of Moving Side \& Forward (1967; Fig. 2) is so exquisitely fleeting that we wonder if we have seen this child at all, especially since the figure group to the right is so solid by contrast. Given the recent discussion of Chambers's "unfinished" painting Lunch $^{8}$ - a work prominently featured in the Art Gallery of Ontario's 2011-12 exhibition Jack Chambers: Light, Spirit, Time, Place and Life - one might wonder if Three Sisters Waiting and Moving Side \& Forward are finished. But this is a question that limits our understanding: Chambers's work is rarely "finished" in the sense that it stays in its moment in static fullness. Many of his paintings' surfaces are purposefully rough; suggestions of narrative in the films are always interrupted; the silver paintings of 1966-67 flicker from positive to negative, depending on the light and the viewer's movements; his thousands of photographs always seem on the way to being something else in a painting, as his aesthetic often compelled them to be. Even his seemingly still and perfect perceptual realist paintings such as Victoria Hospital (1969-70) hover between the frank materiality of the mundane present and a timeless transcendence.
Here we have an example of the paradox of the regional: Chambers was born and died in this hospital, yet his highly articulate theory of "perceptual realism" or "perceptualism" (as he tended to call it in the 1970s), emphasized the distance the work must have from such particulars. Perceptualism, he writes in his autobiography, is a "faculty of inner vision... The inspiration always belonged to the object" (122) rather than to a strictly personal recollection or association.

Chambers was not inclined to final pronouncements. Woodman, who knew him better than anyone outside his immediate family, describes him as "ever restless." 9 He kept his work moving: literally in film, optically in the "instant movies" (his memorable description of the aluminum pigment paintings of the 1960s), and mnemonically, whether in recollections of past European art or of more recent and local events. The all silver Middle 1 of 1966 (Fig. 3), for example, produced as a large painting and as a multiple, combines an image of Jean Auguste Dominique Ingres's famous La grande odalisque (1814) a powerful cipher of past European classicism-with what looks very much like a self-portrait. Chambers's remarkable films, more than any other of his works, are of London and the surrounding area. Mosaic (1966) combines footage of Chambers's wife Olga with shots of London. R 34 (1967) focuses on his friend and fellow artist Greg Curnoe's quotidian creative

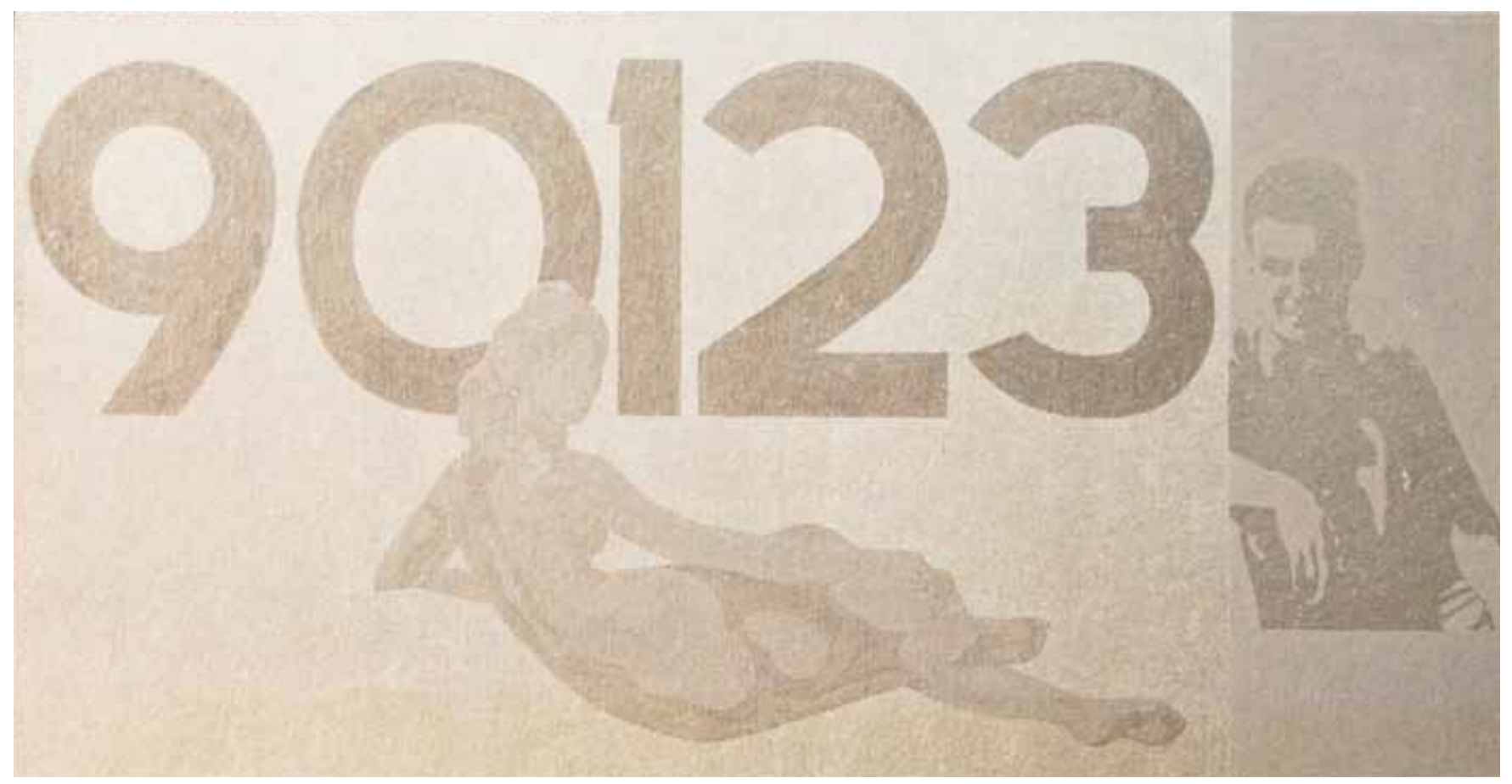

Figure 3. Middle I, 1966. Multiple (2 views). Aluminum and mixed media paint on board, $38 \times 71 \mathrm{~cm}$. Mclntosh Gallery, Western University (Photo: Western University). 


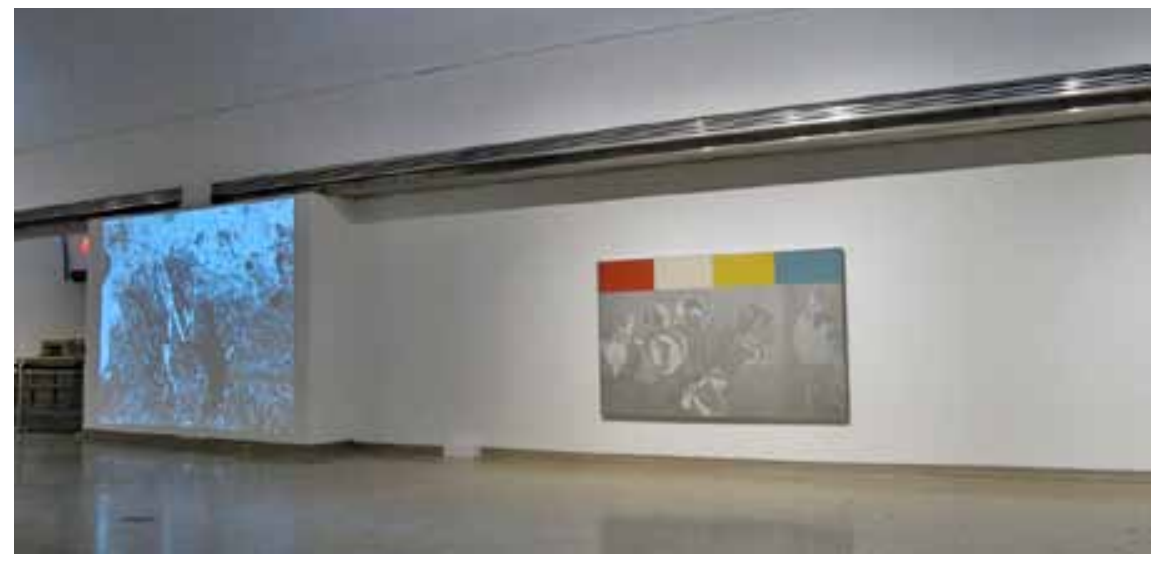

Figure 4. Installation shot from Museum London exhibition, Jack Chambers: The Light from the Darkness (20II), showing a still from Hybrid and Tulips with Colour Options (Photo: Ihor Holubizky). routine. Long portions of Circle (1968-69) and Hart of London (1968-70) notoriously use found footage lifted from local media sources. In Circle, this material frames the camera's diurnal picturing of Chambers's backyard for a year. Hart of London explores the local in detail using images that Chambers gleaned from residents: we see London's factory workers and their bosses, business as usual in a small town. We follow the police as they track a deer through the apparently quiet backyards of domestic London. Here Chambers shows us both the banality and cruelty of the local. As Woodman writes, "Hart of London explores the nightmare from which he fled." 10

In the profoundly meditative Circle, Chambers supplements the mesmerizing year-long record of his own backyard with domestic scenes of local children frolicking in the snow, of life's cycle playing out in innocence. The film ends with a bird released from a hand. The creature soars away from its captivity, escaping physical constraints and even time, just as Chambers's camera does as it sweeps above the landscape of Springbank Park in London at the conclusion of Hart and in sequences from his last and unfinished film, C.C.C.I. While we view these transcendent scenes as Hart ends, Chambers's soundtrack repeats Olga's warning to their sons John and Diego: "You have to be very careful." Initially, this whispered caution was immediate and practical: the boys were feeding deer in the park. Yet her words move beyond place and time entirely to comment on our mortality.

Many aspects of Chambers's work are both homegrownbecause they seem to depict familiar surroundings in an accessible manner-and also engage the occasional strangeness of this apparent familiarity by picturing known landscapes peopled by surreal ancestors (Fig. 1). Other dimensions, however, oppose the iconography of the domestic with disturbing, alien subject matter. Nowhere is this clearer than in Hybrid (1967; Fig. 4), Chambers's anti-Vietnam War film, made and screened to raise money for victims of the war. Here he juxtaposes the manipulations of a horticulturist performing grafts and the time-lapse unfolding of a rose with still images of the horrors of the Vietnam War as visited on the bodies of its many civilian victims. What seem like opposed poles - the quiet and methodical hybridization of soon to be beautiful flowers and the cataclysms of imposed geopolitical will-come together as a shocking revelation of the hubris and violence of human interventions. Hybrid is both plainly local and obviously foreign; the two extremes coalesce not only thematically but in Chambers as a man and artist. He used local film that reminded him of happy times with his grandfather, an avid gardener, and he travelled to New York City in the mid-1960s expressly to retrieve images of the destruction of the Vietnam War for this film. Violence is somehow in us, he suggests here and in much of his work. Violence as well as rebirth focus Hart of London both formally - the centrally placed abattoir and birth sequences—and thematically.

Hybrid is not the anomaly in Chambers's work that it might seem to be. Chambers shows us how flowers are beautiful living entities cultivated for our enjoyment, yet made complicit in a darker human propensity. They are pruned and developed so that they may unfold spectacularly in the time-lapse sequences, a new technology that fascinated him. Going beyond Hybrid, we can say that flowers and the way people use them are for Chambers indicative of the interpenetrations of the regional and the imported, even of the alien. In Tulips with Colour Options (Fig. 4; 1966) for example, the flowers are local, even personal. They are derived from Chambers's own photographs yet contrasted - as in the two portraits in Middle 1-with intruders, in Tulips with an allusion to American colour field abstraction across the top, and in both cases with reproductions of paintings by Ingres that betoken European high culture, a set of traditions cultivated through centuries of careful manipulation 
and much admired by Chambers in his 1969 manifesto "Perceptual Realism." In the form of seventeenth-century still-lifes, flowers in Chambers's paintings frequently suggest the vaunted standards of European classicism - itself a highly controlled and controlling style-as in Renaissance Still-Life (1966) and in Madrid Window No. 1 (1966) and No. 2 (1968-69). In Madrid Window No. 2 especially, we see Chambers's frequent strategy: the meticulously rendered European still-life is interrupted by a two-frame inset that reveals an image of Olga with one of their children and another of a bird. The bird recalls the closing sequence of Circle, which Chambers was making at the same time. Chambers's habit of repeating and extending motifs from the European classical tradition, which he actively emulated through his own personal memories and associations of place and locale in the London area, is what marks his regionalism as an inner value, one he sought to explain by describing perceptualism in his autobiography as a "faculty of inner vision" (122). How, finally, do we square the regional and what, to cover the range of possibilities in this category, one could call the extra-regional in Jack Chambers's work? He shows us that these dimensions of reality necessarily coexist everywhere if we can only perceive them: in London, in the artist, in the dynamic of human memory, and especially in the play of the conscious and the unconscious, that palpable theatre of the mind that his films mirror so powerfully.

One important key to the questions about the regional in Chambers's work comes from the realization that his visual explorations of the local-his regionalism-find parallels in his seminal essay "Perceptual Realism." He reports in his autobiography that he began to write on this subject because "there was no critical differentiation between one approach to realism and another" at the time (120). One reason for this lack, he argues, is that "those in Canada who wrote about art had never been exposed to classicism" (122), by which he meant the time-tested and rigorous naturalistic art of Europe that he studied and perfected in Spain. Chambers opens this difficult essay with a contrast between the new North American technological society and that of European tradition. "The visual-industrial heritage of North America does not include a tradition in sculpture or painting. Such a culture has a very different attitude and appearance from a culture within a tradition, like Spain," he claims (7). It is the regional instantiation of this industrialism that he shows in Hart of London. Strikingly, but not surprisingly given his experimentation in Circle, Chambers uses horticultural metaphors in this essay to describe what he is trying to do in London: "Historic technology of art ripens into periods of fruitfulness and decays like any natural thing. The recurrent blooms of this organism to which I am attracted are the emergence of the forms of classicism and any art which advances these forms" (7). He seeks a native classicism, one that is nur- tured locally, not imported. For Chambers, this in part means using the technology of photography to steady his perception, to offer a reliable point of reference for visual information. "What I want from the camera technically," he writes, "is a precisionin-depth colour description" (8). If we note that the examples of his procedures and goals that he cites and illustrates in the essay are Sunday Morning No. 2 and 401 Towards London No. 1 (both 1968-69), we could say that the camera assures him of the look of the local because it records such scenes without purposeful, authorial editing. But Chambers does not transfer his vision of the region in a simple or total way. Near the end of "Perceptual Realism" he underlines the confluence of places and influences that must collaborate to make his technique successful: "Perceptual realism incorporates two systems of technology (historic and industrial) and two systems of visibility (body and mind) to structure a reflector-object of experience.... It is an object to see with rather than a thing just to see" (13). Both Sunday Morning No. 2 and 401 Towards London No. 1 are more than domestic or local records. They are epiphanies that take the immediate only as their occasion. As Chambers elaborates this notion in his autobiography, "this vision cannot be duplicated in painting because for the visual sense there is nothing to see: the names and games of the conceptual mind are inoperative during the perceptual moment" (122). In one sense, then, it seems that the epiphany of perceptualism could be triggered anywhere; however, it also depends on the deep mnemonic associations that the artist, and potentially the viewer, have with what is depicted.

It is not often noticed in the literature on Chambers that the next section of "Perceptual Realism" is an enigmatic but perceptive commentary on Marcel Duchamp. So normalizing is the superficial reading of Chambers the regionalist that his remarks on the famous French artist who transplanted to New York can seem out of place in London, Ontario. They have been ignored because they don't fit with this common view of Chambers. But a regional art must be informed; otherwise, one could argue, it becomes merely parochial. Chambers understood Duchamp's radical intrusions into the art system as illustrations of a much larger importation: "North America's first import was her own settling people," he says, "a coherent mental system removed from its organic container-body in Europe and deposited as a mind-import of uprooted human beings carrying the industrial heritage of the Renaissance to a carte-blanche opportunity God-given pragmatism." He continues, "Duchamp's 'odd' objects in the 'right' place appear to enact in art the divided status of body and mind in North America" (13). Clearly Chambers had thought about Duchamp's readymades and integrated them into his own system: 


\section{CHEETHAM | Squaring Circles}

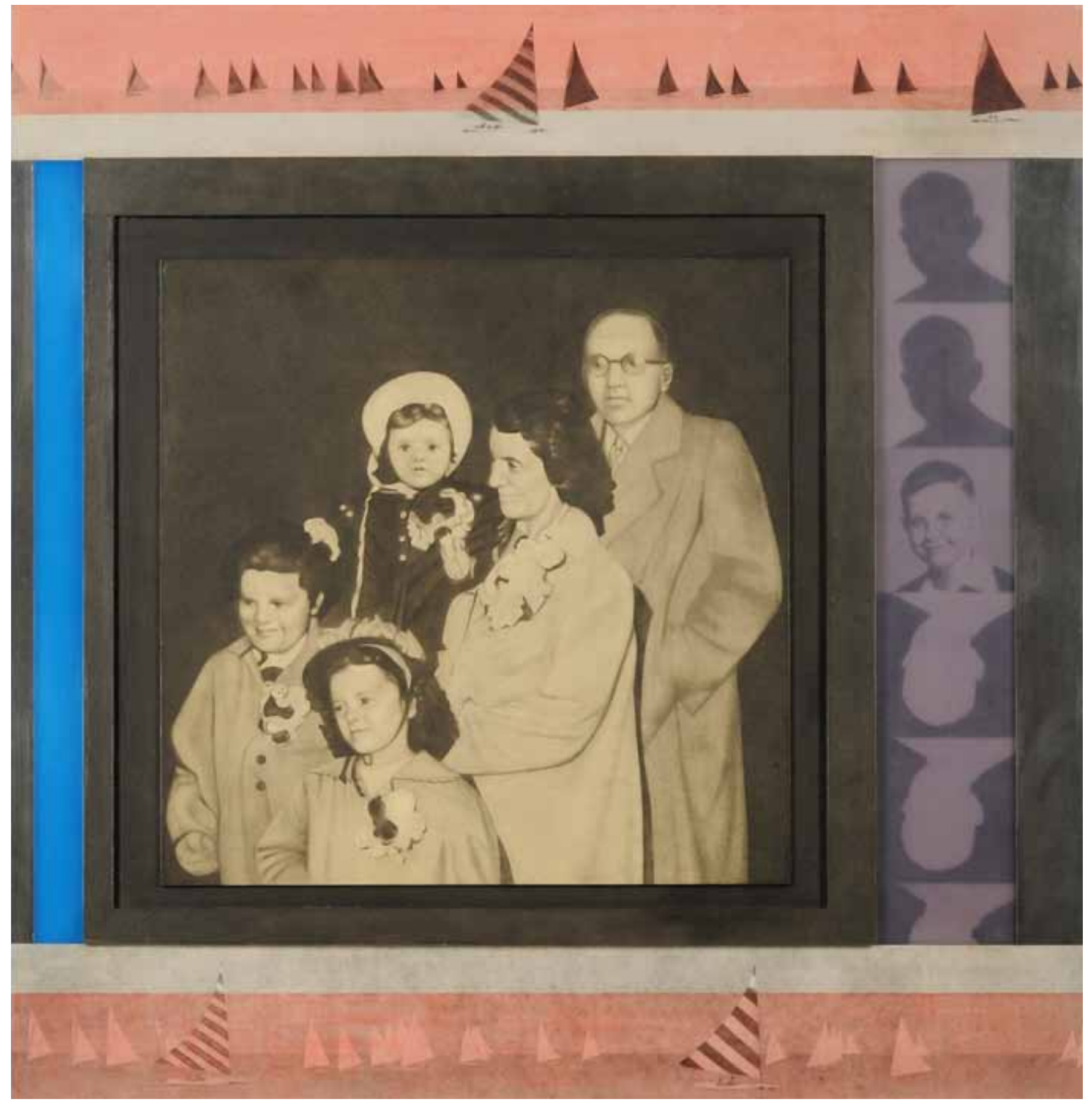

Figure 5. Regatta No. I, 1968. Oil and graphite on paper, mounted on Plexiglas, $129.5 \times 122.5 \mathrm{~cm}$. Collection of Museum London, Gift of the Women's Committee, 1968 (Photo: Museum London). 


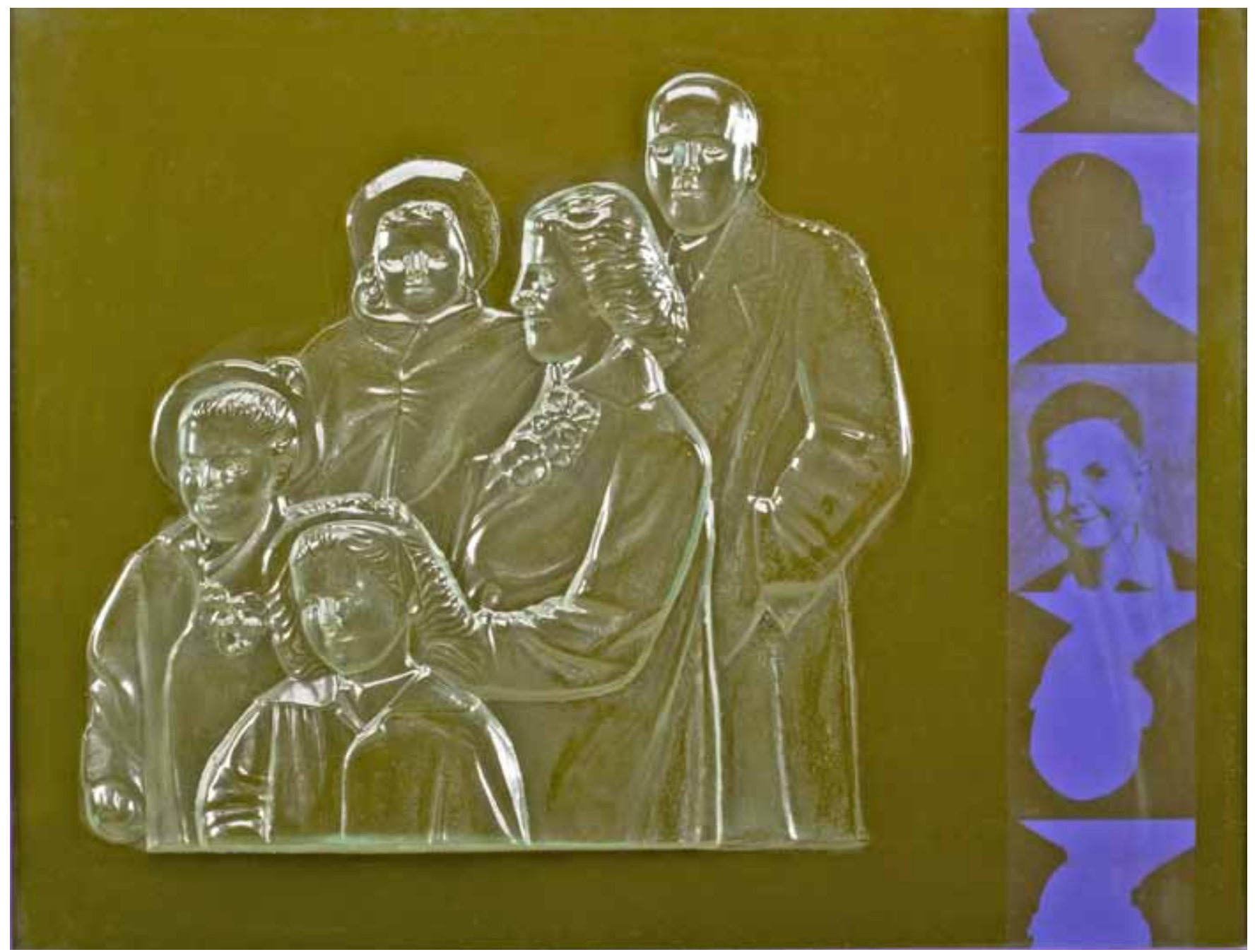

Figure 6. Regatta No. 5, 1968-69. Vacuum-formed plastic, paper, acrylic, $77 \times 100$ cm, gift of the Estate of Jack Chambers, 2007. Art Gallery of Ontario (Photo: Art Gallery of Ontario).

The displacement aspect of Duchamp's art reveals to North America its deeper sentiments about itself: its uprootedness. North American Dada, random objects, factory-art, earthworks, natural environment tours is its awareness of the submerged raw-longing about rooting its condition in origins as origin is perceived in Duchamp's art (13).

Chambers seeks to calm this sense of displacement in himself and in his society through the transcendent continuities captured in perceptual realism. This he accomplishes with regional subject matter to be sure, but as in "Perceptual Realism," also by including "foreign" material.

This pattern appears in two closely related works, Regatta No. 1 of 1968 (Fig. 5) - which is not a fully perceptualist work for Chambers because he began it before articulating the theory in 1969 and because it contains a range of elements, described below, that tend to take away from the unitary focus characteristic of perceptualism - and the film Hart of London, which is central to this category. Regatta No. 1 garnered Chambers an award at the Art Gallery of Ontario's Canadian Artists '68, juried by British Pop artist Richard Hamilton, New York avantgarde film maker Jonas Mekas, and Scottish sculptor William Turnbull (Chambers also won first place in another category for his film $R 34$ ). Regatta No. 1 is a remarkably layered collaboration of images and abstract colour, truly a pivotal work. In its reliance on photographic and film images - the central family group, the regatta taking place at the top and bottom margins of the image, and the photo of the young boy whose 
tragic death in a boating accident the construction commemorates-Regatta No. 1 is continuous with the silver works that precede it. But it is not a painting. Like Moving Side \& Forward (Fig. 2) and Bird Plant (1967-68), it is a drawing mounted on Plexiglas, a "plastic drawing." Regatta No. 1 is in many ways decidedly regional. The mourning family is drawn from a local newspaper photograph. The delicately animate sailboats derive from film footage Chambers also used in Hart of London. The image of the lost boy is again ghostlike: his smiling, schoolphoto-like face is eerily framed by positive and negative silhouettes of his head. He is present and yet gone, like a photo or a movie.

The poignancy of this apparition is even more stark in subsequent members of this series. In the next iteration, Regatta No. 2 (1968-69), Chambers has the grieving family on the left face a double contact strip of mostly negative images of the drowned boy on the right. Regatta No. 5 (1968-69, Fig. 6) changes the colour and keeps the boy on the right side of the image. In Regatta No. 6 (1968-70) this focus on the boy's head is again repeated, but now underneath the central group and overlaying the image of the regatta itself. Regatta No. 1 and No. 2 deploy layers of intensely hued blue Plexiglas, suggesting not only the theme of water but also an allegiance to international artworld experiments with plastics at this time. The later regatta works are in vacuum form, an experimental low relief technique that also employed plastic. In this way Chambers combines the regional and the non-regional, the familiar and the new.

Chambers more often than not chose to include what one could call an avant-garde element in his work as a counterpoise to the local. This conscious habit made his regional inflection potent. Making what he called "personal films" at all is the overarching example. On a more immediate plane of reference, he says that the tonal simplicity of his silver paintings-a series that he undertook in part as a relief from the complexity of manipulating colour-led him back to drawing by 1967 . We might construe this move as a retreat to the classicism of his time in Spain. ${ }^{11} \mathrm{He}$ even considered returning there and apprenticing himself to a wood carver. He made "three-dimensional landscapes" in these years and described them at length in his 1978 autobiography. Yet instead of moving back technologically to hand work or personally to his student haunts, in the Regatta series, Chambers experimented not only with Plexiglas-which provided high keyed colour without applying pigment-but also with another new three-dimensional technique, vacuumform plastic, working with the machinery at London's Fanshawe College. This medium held the triple advantage of being three dimensional, visibly new, and amenable to the production of multiples.

In "Perceptual Realism," Chambers pledged to use technologies founded in North America as opposed to impor- ting those of Europe in bad faith. Photography is crucial in this regard, as is film:

With all there is to explore in electrical-science technology, as well as new meanings that will transform other things, the experimental characteristic of North America will eventually create its own historic dimension with its own technology. Where North America will eventually create its own historic dimension is in the medium of personal film-making (13).

Chambers makes this art form regional as well as indigenous to North America. As it was in the Regatta works, the imagery and ethos of Hart of London is almost entirely of the city and its inhabitants. Hinting at the trajectory of this compendium of local detail, the late American filmmaker Stan Brakhage thought that it "shows every conceivable foolishness," 12 not so much of Londoners but of humanity. Those who know the film can readily supply examples, from the relentless pursuit of a deer through suburban backyards to the repetitious slaughter of its kin by self-satisfied hunters. Chambers famously gathered donated images of London and merged them with TV film footage of the area, yielding in the first part of the film an ever faster welter of regional imagery and memory. Not infrequently, though, we see footage that he shot in Spain. A landscape looks different; people look different. These interruptions of the regional should prepare us to notice that the graphic, structural, and thematic juxtaposition of death and birth that centres the film-the abattoir and hospital delivery room scenes-also furnishes a contrast between the local birth and the butchers' routine, which Chambers filmed in Chinchón, Spain. Yet both of these powerful sequences could take place anywhere. As the soaring camera at the end of the film reminds us, the immediate, regional references are ultimately transcended.

In an exhibition for Museum London in 2006, curator Ihor Holubizky skillfully surveyed the questions and challenges of regionalism as a concept and practice. He emphasized that there was and is "radical regionalism," a regionalism that engages with pressing aesthetic and social concerns, despite the fact that the term regional often implies retrenchment in the minds of those weaned either on the international avant-garde or contemporary globalism. ${ }^{13}$ Holubizky's exhibition-which did not include the usual regional suspects, Curnoe and Chambers-is also a potent reminder of the strength of Chambers's vision at a time when the regional in its Southwestern Ontario guise had just gone national. In December 1969 Ross Woodman mused on the import of Pierre Théberge's then recent exhibition The Heart of London, which was seen in the National Gallery of Canada as well as in its namesake. Writing with his unequalled access to and insight into Chambers's ideas and working processesand while Hart of London was still being made-Woodman wrote that Chambers's vision of his city through an "essentially 
unscripted image of itself...may help to render visible the reality hidden beneath the colonial mask" of London. Tongue in cheek, he continued: "The impact of London regionalism is gradually being felt even in London." 14 Never a parochial commentator, Woodman ends his article by proclaiming that "the international recognition London art has received...has, of course, little to do with its actual subject matter. It has to do with its radically experimental techniques that often... reflect and even anticipate the most advanced art being produced anywhere." Chambers's regionalism was international by design; his transnational perception was rooted locally in the personal, in memory, and in the concomitant experience of the self in place.

\section{Notes}

1 Chambers "expressed a notion of regionalism not based on a nostalgic and sentimental restrictiveness but on a celebration of the reality of living and working in a particular place." The Canadian Encyclopedia. http://www.thecanadianencyclopedia.com/articles/ jack-chambers. Accessed 22 January 2013. Other examples of this view include Joan Murray in Canadian Art in the Twentieth Century (Toronto: Dundurn Press, 1999), 91, and David Burnett and Marilyn Schiff, Contemporary Canadian Art (Edmonton: Hurtig Publishers Ltd. in co-operation with the Art Gallery of Ontario, 1983), 173.

2 Jack Chambers, Jack Chambers (London, Ont.: Nancy Poole, 1978). Page references to this essay appear in my text.

3 Ross G. Woodman, Chambers: John Chambers Interviewed by Ross G. Woodman (Toronto: Coach House Press, 1967), 5-7

4 Dennis Reid, "Jack Chambers: The Man, the Life, the Practice," in Dennis Reid, ed. Jack Chambers: Light, Spirit, Time, Place and Life (Fredericton, NB: Goose Lane Editions; Toronto: Art Gallery of Toronto, 2011), 28.

5 Ross G. Woodman, "Jack Chambers," Border Crossings 118 (May 2011), 105.

6 Chambers's radicality is explored in the exhibition and catalogue Jack Chambers: The Light From the Darkness/Silver Paintings and Film Work, curated by Mark A. Cheetham and Ihor Holubizky, Museum London (London, Ont., 2011).

7 The upsurge in critical attention to Chambers may finally change this unfortunate bias and make it more likely that we will consider the films, paintings, and drawings together. In an essay titled "Painting in his Time" for "The Silence of Jack Chambers" project at the Central Public Library in London in 1998 (20 years after Chambers's death), Andy Patton asked pointedly: "why is Jack Chambers thought of, and presented as, a 'painter'-when he wasn't, when he was simply an artist in the widest sense of the word?” In Ron Benner et al., The Silence ofJack Chambers (London, Ont.: Central London Public Library, 1988), n.p. Ross Wood- man's essay for the 1980 exhibition and catalogue Jack Chambers: The Last Decade (London, Ont.: London Regional Art Gallery, 1980), Tom Graff's number of The Capilano Review devoted to Chambers's film work (No. 33, 1984), Bruce Elder's attention to Chambers in Image and Identity: Reflections on Canadian Film and Culture (Waterloo, Ont.: Wilfrid Laurier University Press, in collaboration with the Academy of Canadian Cinema \& Television, 1989), "The Jack Chambers Film Project" in 2001, and Kathryn Elder's collection The Films of Jack Chambers (Toronto, Cinematheque Ontario; Bloomington: Indiana University Press, 2002), have also re-established the importance of his films. Adam Welch has made the crucial point: "Necessary to an understanding of his practice in the late 1960s, Chambers' films must not only be considered a parallel practice or analogous to his paintings, but rather as expressions derived from the very same shared set of concerns and problems." "'Between Aluminum and Celluloid: Jack Chambers' Expanded Art, 1966-1967," in Cheetham and Holubizky, eds., Jack Chambers, 53). One of those fundamental concerns was the nature of the regional.

"Perceptual Realism" appeared in Artscanada 26, 136-37 (October 1969): 7-13. Page references to this essay appear in my text.

8 Sara Angel, "Unfinished Business," The Walrus (January-February 2012). http://thewalrus.ca/unfinished-business/ Accessed Jan. 23, 2013.

9 Ross G. Woodman, "Space," in Dennis Reid, ed., Jack Chambers, 111.

10 Woodman, "Space," 111.

11 Scholars have waited a long time to understand more completely Chambers's time as a student and budding professional artist in Spain. Invaluable documentation and interpretation is found in Simon Bentley's MA Thesis from Western University, "Jack Chambers and the New Spanish Realists," 2011.

12 Stan Brakhage speaking at "The Jack Chambers Film Project," London, Ontario, 2001.

13 Ihor Holubizky et al., Radical Regionalism: Local Knowledge and Making Places, exh. cat., Museum London (London, Ont., 2006).

14 Ross G. Woodman, "London: Regional Liberation Front," The Globe and Mail, 13 December 1969, 27. 